Jurnal Psikologi Teori dan Terapan

2016, Vol. 6, No. 2, 113-118, ISSN: 2087-1708

\title{
Regulasi Diri dengan Burnout pada Guru
}

\author{
Sysditya Ekawanti, Olievia Prabandini Mulyana \\ Program Studi Psikologi Universitas Negeri Surabaya
}

\begin{abstract}
Teachers begin to experience symptoms of fatigue due to heavy workload characterized by working ineffectively in the classroom so that the interest of the students declined. This study aims to test whether there is relationship between selfregulation and burnout in teachers. The population was junior high school's teacher. This study use population research, where all the population used as a sample. Researchers use all certified teachers in the school, participants are 35 teachers. The approach used is quantitative method. Data collected using self-regulation and burnout scales, and analyzed using pearson product moment correlation test. The results obtained from this study indicate that there is a significant relationship between selfregulation with burnout in teachers. Significant relationships are seen from the p-value of 0.017 and $r$ value of -0.401 . The $r$ value indicates that the relationship between the two variables have a negative direction, meaning that the higher of self-regulation, the lower of burnout. Individual's good self-regulation be able to cope stress and emotions, because of burnout arising drag on stress experienced by the individual.
\end{abstract}

Key words: self-regulation, burnout, teacher

\begin{abstract}
Abstrak: Guru mulai mengalami gejala kelelahan akibat beban kerja yang berat yang ditandai dengan kurang bekerja efektif didalam kelas sehingga minat kepada peserta didik menurun. Penelitian ini bertujuan untuk menguji apakah ada hubungan antara regulasi diri dengan burnout pada guru. Populasi penelitian ini adalah guru SMP. Penelitian ini menggunakan penelitian populasi, dimana semua populasi digunakan sebagai sampel penelitian. Peneliti menggunakan semua guru yang sudah sertifikasi di sekolah tersebut yang berjumlah 35 orang guru. Pendekatan yang digunakan ialah kuantitatif. Data dikumpulkan menggunakan skala regulasi diri dan burnout, dan dianalisis menggunakan uji korelasional pearson product moment. Hasil yang diperoleh dari penelitian ini menunjukkan bahwa terdapat hubungan yang signifikan antara regulasi diri dengan burnout pada guru. Hubungan yang signifikan tersebut dilihat dari nilai $\mathrm{p}$ sebesar 0,017 dan nilai $r$ sebesar $-0,401$. Nilai $r$ tersebut menunjukkan bahwa hubungan kedua variabel memiliki arah negatif, artinya semakin tinggi regulasi diri maka semakin rendah burnout. Regulasi diri yang baik yang dimiliki individu akan mampu mengatasi stres dan emosi dalam dirinya, karena burnout timbul akibat stres yang berkepanjangan yang dialami individu.
\end{abstract}

Kata kunci: regulasi diri, burnout, guru

Pendidikan merupakan sesuatu yang penting bagi semua orang, sebagaimana fungsi pendidikan nasional bahwa pendi- dikan merupakan akar dalam mengembangkan kemampuan dan membentuk watak serta peradaban bangsa yang ber-

Korespondensi tentang artikel ini dapat dialamatkan pada Sysditya Ekawanti melalui email: sysditya@yahoo.co.id 
martabat dalam rangka mencerdaskan kehidupan bangsa (Faturrahman, 2012).

Pada beberapa tahun terakhir, sertifikasi pendidik telah dilaksanakan guna mengangkat derajat kesejahteraan guru. Saat ini guru dituntut lebih professional dengan berbagai kewajiban yang harus dipenuhi, sehingga peserta didik terlayani sebagaimana yang diharapkan. Guru akan menyerah pada gejala kejenuhan, termasuk meningkatnya kekerasan di sekolah, kurangnya dukungan dari masyarakat sosial, tekanan pekerjaan, konflik peran dan ambigiusitas, tekanan dokumen, dan karakteristik kepribadian individu. Seorang guru yang memiliki dan menyadari tanggung jawab, tujuan dan niatan untuk mensukseskan anak didiknya, dan mampu memegang teguh tujuan tersebut serta bekerja ikhlas, maka guru tersebut telah mampu memberikan layanan sosial terbaik kepada peserta didik dan wali murid dengan mengontrol dan mengarahkan tindakannya sendiri, meski terdapat banyak tekanan dan tantangan dalam proses tersebut.

Burnout merupakan keadaan dimana individu merasakan stres dalam jangka waktu yang lama dan dengan intensitas yang cukup tinggi, ditandai dengan kelelahan fisik, mental, dan emosional, kurangnya perhatian kepada orang lain maupun pekerjaan akibat dari tekanan berkepanjangan yang dialami dalam situasi kerja, terutama pada pekerjaan pelayanan sosial, serta rendahnya penghargaan terhadap diri sendiri yang mengakibatkan individu merasa terpisah dari lingkungannya (Sihotang, 2004). Burnout berbeda dengan stres, burnout menyebabkan orangorang yang sebelumnya sangat berkomitmen pada pekerjaan mereka menjadi kecewa serta kehilangan minat dan motivasi. Burnout sering dihubungkan dengan krisis paruh baya atau paruh karier, namun hal tersebut bisa terjadi di waktuwaktu yang berbeda pada orang-orang yang berbeda. Ketika hal tersebut muncul, mereka bisa kehilangan motivasi mereka untuk berprestasi. Burnout merupakan faktor paling umum yang menyebabkan keputusan untuk berhenti bekerja sementara (Mondy, 2008).

Menurut Maslach \& Jackson (1981), burnout merupakan suatu sindrom psikologis yang terdiri dari tiga karakteristik, yaitu: kelelahan emosional, depersonalisasi, penurunan pencapaian kepuasan diri.

Kelelahan emosional ditandai dengan terkurasnya energi yang dimiliki, berkurangnya sumber-sumber emosional dalam diri seperti rasa kasih, empati, dan perhatian, yang pada akhirnya memunculkan perasaan tidak mampu lagi memberikan pelayanan kepada orang lain. Di sisi lain, depersonalisasi merupakan sikap, perasaan, maupun pandangan negatif terhadap penerima pelayanan. Sedangkan penurunan pencapaian kepuasan diri ditandai dengan kecenderungan memberi evaluasi negatif terhadap diri sendiri, terutama berkaitan dengan pekerjaan.

Pada studi pendahuluan, peneliti menemukan beberapa fakta di lapangan, yakni masih ada beberapa guru yang sudah sertifikasi namun masih sering terlambat mengajar di kelas, terlambat masuk kerja padahal sekolah sudah menyiapkan absensi elektronik, terkadang guru hanya memberikan tugas pada peserta didik dikelas, namun guru tetap berada di kantor, guru acuh tak acuh dengan kondisi siswa, beberapa guru mengajar dengan pola lama yang terkesan monoton, membosankan, dan tidak kondusif, guru merasa jenuh dan lelah dengan kegiatan program peningkatan mutu dan bimbingan belajar hingga sore hari, guru mudah tersinggung dengan sesama guru, dengan peserta didik, atau bahkan dengan wali murid, serta guru yang marah dan meninggalkan ruangan kelas saat proses belajar mengajar berlangsung, karena ada peserta didik tertentu yang mengganggu kegiatan belajar mengajar.

Kinerja para guru lebih terkontrol jika kepala sekolah memonitor dan memberikan teguran jika terdapat kesalah- 
an seperti halnya guru yang tidak segera masuk kelas saat jam mengajar, guru yang absen tidak masuk tanpa keterangan, ataupun guru yang terlambat datang ke sekolah.

Regulasi diri berkaitan dengan bagaimana seseorang menampilkan serangkaian tindakan yang ditujukan untuk pencapaian target dengan melakukan perencanaan terarah (Zimmerman, 1990). Menurut Pintrich \& De Groot (1990), regulasi diri merupakan suatu kegiatan belajar yang diatur oleh diri sendiri, yang di dalamnya individu mengaktifkan pikiran, motivasi, dan tingkah lakunya untuk mencapai tujuan. Kemampuan individual untuk memiliki pengendalian diri dalam dirinya sendiri, itulah yang menjadi sorotan penting dalam regulasi diri (Prasad, Lim, \& Chen, 2010).

Menurut Zimmerman (2008), regulasi diri mencakup tiga aspek, yaitu: metakognitif, motivasi, perilaku. Poin metakognitif bagi individu yang melakukan pengelolaan diri adalah individu yang merencanakan, mengorganisasi, mengukur diri, dan menginstruksi diri sebagai kebutuhan selama proses perilakunya.

Sedangkan aspek motivasi merupakan strategi yang digunakan individu untuk mengatasi stres dan emosi, yang dapat membangkitkan usaha mengatasi kegagalan dan untuk meraih kesuksesan dalam belajar. Selain itu, menurut Zimmerman, yang termasuk dalam aspek perilaku adalah penataan lingkungan, menyimpan catatan dan pengawasan, mengkaji teks, catatan, dan tes.

Uraian di atas menunjukkan bahwa burnout merupakan suatu permasalahan yang menarik untuk dikaji lebih lanjut melalui tinjauan psikologi. Karena itu, penelitian ini dilakukan untuk menguji hubungan regulasi diri dengan burnout pada guru.

\section{Metode}

Penelitian ini menggunakan metode penelitian kuantitatif dengan rancangan penelitian korelasional untuk mengungkap hubungan antara regulasi diri dengan burnout pada guru.

Populasi dalam penelitian ini adalah tenaga pendidik (guru) di salah satu sekolah di Sidoarjo dengan jumlah total 50 guru. Penelitian ini menggunakan teknik sampling jenuh dengan menggunakan keseluruhan populasi sebagai sampel penelitian. Guru sebanyak 15 orang digunakan peneliti untuk uji coba skala, sedangkan 35 orang lainnya digunakan untuk sampel penelitian.

Instrumen yang digunakan dalam penelitian ini adalah skala regulasi diri untuk mengukur variabel regulasi diri dan skala burnout yang digunakan untuk mengukur variabel burnout dengan menggunakan skala likert. Skala regulasi diri dan burnout disebarkan kepada subyek penelitian yakni guru salah satu sekolah di Sidoarjo.

Teknik analisis statistik yang digunakan adalah analisis korelasi uji pearson product moment yang bertujuan untuk mencari hubungan antar variabel yaitu variabel regulasi diri dan variabel burnout. Analisis korelasi pearson product moment dilakukan setelah melakukan uji asumsi yang terdiri dari uji normalitas dan uji linieritas.

\section{Hasil dan Pembahasan}

Berdasarkan hasil analisis data yang dilakukan dengan menggunakan korelasi pearson product moment dapat diketahui $r$ $=-0,401$. Terdapat tanda negatif (-) didepan nilai korelasi $(0,401)$ yang berarti bahwa korelasi memiliki pola negatif atau terbalik (X naik maka $\mathrm{Y}$ turun) semakin tinggi regulasi diri maka semakin rendah burnout.

Berdasarkan taraf signifikansinya, diketahui nilai $\mathrm{p}=0,017(\mathrm{p}<0,05)$ sehingga terdapat hubungan yang signifikan antara variabel regulasi diri dengan burnout, artinya hipotesis penelitian yang ini diterima, yaitu ada hubungan yang signifikan antara burnout dan regulasi diri 
guru. Regulasi diri yang baik yang dimiliki individu akan mampu mengatasi stres dan emosi dalam dirinya, karena burnout timbul akibat stres yang berkepanjangan yang dialami individu. Stres dapat diatasi dan kecenderungan burnout akan sangat kecil jika individu tersebut memiliki regulasi diri yang baik yang dapat menekan dan mencegah terjadinya stres, karena individu tersebut akan dapat mengontrol dan mengarahkan dirinya untuk mencapai tujuan yang diinginkan.

Adanya hubungan antara regulasi diri dengan burnout pada guru sesuai dengan penelitian yang dilakukan oleh Adawiyah (2013) yang bertujuan untuk menguji hubungan antara kecerdasan emosional dan dukungan sosial dengan kecenderungan burnout pada guru dengan menggunakan analisis statistik regresi dan korelasi parsial. Penelitian yang melibatkan 90 orang guru di sebua SMS Negeri di Bangkalan ini mengindikasikan adanya hubungan negatif yang signifikan antara kecerdasan emosional dan dukungan sosial dengan kecenderungan burnout. Individu yang memiliki dukungan sosial dan kecerdasan emosional yang tinggi cenderung tidak mengalami burnout di dalam bekerja. Namun dalam fenomena burnout sering terjadi bahwa burnout merupakan sindrom dalam dunia kerja yang justru mengenai orang yang berprestasi dan berdedikasi dalam pekerjaannya.

Penelitian yang dilakukan oleh Landeche (2009) menjelaskan bahwa terdapat pengaruh tahun pengalaman kerja dan depersonalisasi yang merupakan salah satu komponen dari burnout. Penelitian lain oleh Sihotang (2004) menjelaskan bahwa jenis kelamin mempengaruhi tingkat burnout, dimana dalam penelitian ini karyawan wanita mengalami burnout lebih tinggi dibandingkan pria. Menurut Maslach (1981), burnout berdampak bagi individu, orang lain, dan organisasi. Burnout merupakan kondisi psikologis yang dialami individu akibat stres yang disertai kegagalan dalam meraih harapan dalam jangka waktu yang lama, yang banyak ditemui pada individu yang bekerja dalam bidang yang berkaitan langsung dengan banyak orang, seperti halnya guru sebagai pelayan masyarakat.

Regulasi diri berkaitan dengan bagaimana seseorang menampilkan serangkaian tindakan yang ditujukan untuk pencapaian target dengan perencanaan yang terarah (Zimmerman, 1990). Adanya hubungan yang signifikan antara regulasi diri dengan kecenderungan burnout menunjukkan bahwa regulasi diri yang baik dapat mendukung berkurangnya kecenderungan burnout. Adawiyah (2013) menyatakan bahwa terjadinya burnout dapat mengkhawatirkan karena memiliki kecenderungan menular. Bila di sebuah sekolah ada guru yang merasa tertekan dan mengalami burnout, guru-guru lain dapat dengan mudah menjadi tidak puas, sinis, serta bermalas-malasan. Tidak lama kemudian, seluruh organisasi menjadi tempat yang tidak menarik dan tidak bersemangat. Karena itu, pencegahan terjadinya burnout pada guru perlu diupayakan dengan baik.

\section{Simpulan dan Saran}

Berdasarkan hasil penelitian, dapat ditarik kesimpulan bahwa hipotesis dalam penelitian ini diterima sehingga dapat disimpulkan bahwa terdapat hubungan yang signifikan antara regulasi diri dengan burnout pada guru.

Bagi peneliti selanjutnya diharapkan dapat meneliti burnout dengan melibatkan faktor-faktor lain yang mempengaruhi antara lain jenis kelamin, usia, dan masa kerja. Sedangkan bagi guru, hasil penelitian ini memberi wawasan bahwa mereka mampu meregulasi dirinya dengan cara membiasakan diri untuk membuat jadwal sehari-hari, membuat catatan kecil untuk mencatat kegiatan yang dilakukan diluar jadwal kegiatan sehari-hari, menentukan skala prioritas untuk mengambil keputusan yang tepat, 
mengelola emosi dengan baik, berpikir positif, dan mengembangkan diri dengan membuat metode atau alat peraga baru untuk mengajar.

\section{Daftar Pustaka}

Adawiyah, R.A.R. (2013). Kecerdasan Emosional, Dukungan Sosial dan Kecenderungan Burnout. Jurnal Psikologi Indonesia. 2 (2): 90-98. Surabaya: Universitas 17 Agustus.

Asizah \& Hendarti, F. (2013). Intensitas Komunikasi Antara Anak Dengan Orang Tua dan Self Regulation pada Remaja Pesantren. Jurnal Psikologi Indonesia. 2 (2): 99-107. Surabaya: Universitas 17 Agustus.

Faturrahman. (2012). Pengantar Pendidikan. Jakarta: Prestasi Pustaka Publisher.

Landeche, P. (2009). The Correlation Between Creativity and Burnout in Public School Classroom Teachers. Tesis. University of Southwest Lousiana. Online. http://etd.lsu.edu/. Diakses 19 Oktober 2014.

Maslach, C., \& Jackson, S. E. (1981). The measurement of experienced burnout: summary. Journal of Occupational Behavior, 2 (2), Online. http://online library.wiley.com/.

Diakses 19 Oktober 2014.Maslach, C., Schaufeli, W. B., \& Leiter, M. P. (2001). Job Burnout, Annual Review of Psychology. 52 (1), Online. http://www.annualreviews.org/. Diakses 19 Oktober 2014.

Mondy, R. W. (2008). Manajemen Sumber Daya Manusia. Jilid Kedua, Edisi Kesepuluh. (Alih Bahasa: Bayu Airlangga). Erlangga.

Pintrinch, P. R., \& De Groot, E. V. (1990). Motivational and Self-Regulated
Learning Components of Classroom Academica Performance. Journal of Educational Psychology. 82 (1), Online. http://web.stanford.edu/. Diakses 19 Oktober 2014.

Prasad, S., Lim, V. K. G., \& Chen, D. J. Q. (2010). Self-Regulation, Individual Characteristics and Cyberloafing. PACIS Proceedings. Paper 152.

Sihotang, I. N. (2004). Burnout Pada Karyawan Ditinjau dari Persepsi Terhadap Lingkungan Kerja Psikologis dan Jenis Kelamin. Jurnal Psikologi, 1 (1), Online. http://fahrudin.weebly.com/.

Diakses 19 Oktober 2014.

Taylor, S. E., Peplau, L. A., \& Sears, D. O. (2009). Psikologi Sosial. Jilid Pertama, Edisi Kedua Belas. (Alih Bahasa: Tri Wibowo). Jakarta: Kencana Prenada Media Group.

Zimmerman, B. J. (1989). A Social Cognitive View of Self-Regulated Academic Learning. Journal of Educational Psychology, 81 (3), Online. http://www. researchgate.net/. Diakses 19 Oktober 2014.

Zimmerman, B. J. (1998). Academic Studying and the Development of Personal Skill: A Self-Regulatory Perspective. Journal of Educational Psychology, 33 (2/3), Online. http://www2.sunysuffolk.edu/. Diakses 19 Oktober 2014.

Zimmerman, B. J.. (2000). Self-Efficacy: An Essential Motive to Learn. Journal of Contemporary Educational Psychology. 25, 
Online. http://www.itari.in/. Diakses 19 Oktober 2014.

Zimmerman, B. J.. (2002). Becoming SelfRegulated Learner: An Overview. Theory into Practice, 41 (2), Online.

http://www.tandfonline.com/.

Diakses 19 Oktober 2014.

Zimmerman, B. J. (2008). Investigating Self-Regulation and Motivation: Historical Background, Methodological Developments and
Future Prospects. American Educational Research Journal, 45 (1), Online. http://aer.sagepub.com/. Diakses 19 Oktober 2014.

Zimmerman, B.J., \& Schunk, D. H. (1994). Self-Regulation of Learning and Performance: Issues and Educational Applications. America: Lawrence Erlbaum Associates Inc. Online. https://books. google. co.id/. Diakses 19 Oktober 2014. 